\title{
Pengaruh Pengetahuan Dan Religiusitas Konsumen Kopi Kekinian Terhadap Minat Beli Kopi Kekinian Yang Telah Memiliki Sertifikasi Halal
}

\author{
Frida Alfi Hidayati \\ Fakultas Ekonomi, Universitas Negeri Surabaya. E-mail: fridahidayati16081194003@mhs.unesa.ac.id
}

\section{Prayudi Setiawan Prabowo}

Fakultas Ekonomi, Universitas Negeri Surabaya. E-mail: prayudiprabowo@unesa.ac.id

\section{ARTICLE INFO}

\section{Kata Kunci:}

Knowledge, Religiosity,

Purchase Intention

\section{Cara Sitasi:}

Hidayati, Frida Alfi \& Prayudi Setiawan Prabowo. "Pengaruh Pengetahuan Dan Religiusitas Konsumen Kopi Kekinian Terhadap Minat Beli Kopi Kekinian Yang Telah Memiliki Sertifikasi Halal." AtTaradhi: Jurnal Studi Ekonomi 12, no. 1 (2021): 36-62

\begin{abstract}
The purpose of this studied was to determine the effect of knowledge and religiosity from modern coffee consumers on the purchase intention of coffee wich currently halal-certified. Type of this studied is quantitative research. Primary data were obtained through a questionnaire with a likert scale as a scale todetermine attitudes on statements from 100 respondents. The results showed that knowledge and religiosity had a positive and significant effect on purchase intention with partially or simultaneously.
\end{abstract}

Tujuan dari penelitian ini adalah untuk menguji pengaruh pengetahuan dan religiusitas konsumen kopi kekinian terhadap minat beli kopi kekinian yang telah bersertifikasi halal. Jenis penelitian ini adalah penelitian kuantitatif. Data primer diperoleh melalui kuisioner dengan skala likert sebagai skala penentu sikap atas pernyataan dari 100 responden. Hasil penelitian menunjukkan bahwa pengetahuan dan religiusitas berpengaruh positif juga signifikan terhadap minat beli baik secara parsial maupun simultan

\section{Pendahuluan}

Kopi merupakan minuman khas yang memiliki banyak penikmat di Indonesia, dengan beragam filosofi yang menyertai menjadikan minuman tersebut saat ini semakin memiliki nilai legendaris dan banyak di gandrungi oleh masyarakat, dimana hal tersebut dapat dibuktikan dengan konsumsi kopi di tahun 2019/ 2020 di Indonesia menurut Global Agricultural Information Network yang mencapai 294.000 ton dan dapat dikatakan mengalami peningkatan sebesar $13,9 \%$ dibanding tahun sebelumnya yang hanya mencapai 258.000 ton. $^{1}$

Dengan konsumsi kopi yang begitu besar dan berkembangnya keadaan, menjadikan kopi memiliki sebutan gaul terutama dikalangan anak muda, yakni kopi kekinian. Kekinian dalam Kamus Besar Bahasa Indonesia $(\mathrm{KBBI})^{2}$ sendiri didefinisikan sebagai keadaan kini atau sekarang, kata tersebut seringkali digunakan untuk mengungkapkan keadaan yang mengikuti zaman. Nama gaul tersebut tidak lain muncul karena kopi semakin memiliki

\footnotetext{
${ }^{1}$ Lit. Dan Nora Azizah Septyaningsih, "Bisnis Ready to Drink Coffee Terus Meningkat," Republika.co.id, 2019, https://gayahidup.republika.co.id/berita/q2ngyv463/bisnis-emready-to-drink-coffeeem-terusmeningkat.

${ }^{2}$ KBBI, “Kamus Besar Bahasa Indonesia (Online)," 2020, https://kbbi.web.id/kini.
} 
banyak inovasi sehingga diminati oleh beragam kalangan dan dapat menjadi peneman dalam keseharian, terutama dengan kandungan kafein dalam kopi yang terbukti mampu memberikan energi bagi penikmatnya terutama dikala kantuk melanda.

Kopi kekinian sendiri dapat dengan mudah dijumpai dalam bentuk sajian menggunakan berbagai cara pengolahan dan berbagai campuran bahan baku selain kopi, dimana hal tersebut terbukti sangat menarik minat masyarakat terutama bagi yang tidak terlalu menyukai cita rasa pahit dari kopi. Inovasi pun juga dilakukan pada basis pelayanan yang kini lebih suka mengusung konsep Coffee to Go yang akan menyediakan fresh RTD (Ready to Drink) Coffee.

Melihat adanya beragam inovasi kopi saat ini menjadikan kita sebagai umat muslim harusnya lebih memperhatikan titik kritisi halalnya, terutama pada bahan campuran selain kopi murni dan alat-alat yang digunakan bersama untuk pembuatan secangkir kopi kekinian di kafe-kafe saat ini. Adapun salah satu contoh produk kopi kekinian yang sangat menarik minat masyarakat adalah kopi susu kekinian yang dibuat dari campuran kopi, susu, dan gula aren ataupun dengan aneka rasa sirup yang manis dan menyegarkan. Dari bahan-bahan kopi susu tersebut tentu yang dikhawatirkan titik kritisi halalnya terletak pada produk kopi (jika bukan kopi murni), gula (jika terdapat penambahan bahan lain dalam proses pembuatan gula), susu (jika bukan susu murni) dan flavour serta alat yang digunakan bersama jika terdapat bahan non halal yang digunakan untuk salah satu produk di suatu kedai kopi atau kafe, jelas Muti Arintawati wakil Direktur LPPOM MUI dalam salah satu artikel yang diterbitkan di laman website resmi LPPOM MUI. ${ }^{3}$

Adapun salah satu contoh bahan flavour yang sering digunakan sebagai campuran bahan dalam kopi kekinian selain bahan utama kopi salah satunya adalah rum dan irish cream. Pada nyatanya rum sendiri tergolong kedalam jenis alkohol kelompok c yang kadar alkoholnya melebihi 20\% dikarenakan rum yang pembuatannya berasal dari tetes tebu atau molase telah mengalami proses fermentasi dan juga destilasi, sedangkan irish cream adalah krim minuman keras yang berbasis wiski Irlandia, krim dan perasa lainnya yang biasanya memiliki tingkat ABV sebesar 15\%-20\%. MUI sendiri sebenarya telah mengeluarkan fatwa MUI nomor 11 tahun 2009 tentang hukum alkohol adalah haram untuk dikonsumsi. ${ }^{4}$ Begitu pula berdasarkan hadits riwayat Ibnu Majah no. $3383^{5}$ bahwa Rasuluallah SAW bersabda: "Setiap yang memabukkan adalah haram, dan sesuatu yang banyaknya memabukean, maka sedikitnya pun haram." Maka dari itu meskipun rum maupun irish cream yang digunakan hanyalah dalam jumlah sedikit, tetap saja rum atau irish cream itu tidak boleh digunakan sebagai bahan campuran pada kopi kekinian yang halal.

Selain itu, kini MUI sendiri juga telah mewajibkan bagi seluruh kedai kopi atau kafe untuk melakukan sertifikasi halal bagi produk dan gerainya. Ketentuan tersebut terletak pada Peraturan Menteri Agama (PMA) nomor 26 tahun 2019 tentang jaminan produk halal, dimana pada pasal 32 telah dikatakan bahwa terdapat penahapan kewajiban untuk produk makanan dan minuman untuk melakukan sertifikasi halal dimulai dari tanggal 17 Oktober

3 (Lembaga Pengkajian Pangan, Obat-obatan, dan Kosmetika Majelis Ulama Indonesia) LPPOM MUI "Kopi? Sudah Pasti Halalkah? Pelajari Titik Kritis Kehalalan Kopi," LPPOM MUI, 2019, https://www.halalmui.org/mui14/main/detail/kopi-sudah-pasti-halalkah-pelajari-titik-kritis-kehalalankopi\#.

${ }^{4}$ MUI (Majelis Ulama Indonesia), Fatwa MUI No. 11 Tahun 2009 “Tentang Hukum Alkohol” (2009).

${ }^{5}$ Abdullah Muhammad bin Yazid bin Majah ar-Rabi'i Al-Qazwini (Ibnu Majah), "Sunan Ibnu Majah,” Pub. L. No. 3383 (n.d.). 
2019 hingga 17 Oktober 2024. ${ }^{6}$ Hal ini sangat penting untuk dilakukan agar semakin banyak kopi kekinian halal yang memang telah tersertifikasi halal oleh MUI beredar dimasyarakat, dan dapat mengurangi penggunakan alkohol maupun tiruan alkohol pada campuran bahan kopi kekinian.

Namun masih banyak ketidaksadaran bagi pemilik kedai kopi atau kafe kekinian pada pentingnya melakukan sertifikasi halal untuk produk atau gerainya, dikarenakan sesuai dengan hasil riset dari TOFFIN yang merupakan perusahaan penyedia solusi bisnis di bidang industri hotel, restoran dan kafe bersama majalah MIX Mar Comm, menyatakan bahwa jumlah kedai kopi di Indonesia per-Agustus 2019 mencapai lebih dari 2.950 gerai, dimana jumlah tersebut menunjukkan peningkatan sebanyak tiga kali lipat dari tahun 2016 yang hanya berjumlah sekitar 1.000 gerai, adapun jumlah tersebut hanya mencakup kedai kopi berjaringan di kota-kota besar belum termasuk jumlah kedai kopi independent yang berkonsep modern maupun tradisional di berbagai daerah, ${ }^{7}$ namun hanya sedikit jumlah kedai kopi atau kafe kekinian yang telah memiliki sertifikasi halal, seperti Starbuck dan Dunkin

Dari data jumlah kedai kopi tersebut menunjukkan jika seringkali pusat kota disetiap wilayah memiliki andil besar dalam meningkatkan jumlah tersebut, seperti halnya di wilayah kota Surabaya yang menjadi salah satu pusat kota di Jawa Timur dengan menduduki posisi kedua sebagai kota padat penduduk dan sebagai pusat pendidikan tingkat tinggi di Jawa Timur dengan 78 perguruan tinggi, juga mayoritas penduduknya memiliki mobilitas tinggi sehingga sangat sesuai dengan kebutuhan para produsen tersebut untuk memberikan penawaran- penawaran produk inovasi mereka yang juga diimbangi dengan basis pelayanan Coffee to Go namun konsumen tetap dapat menikmati fresh RTD (Ready to Drink) coffee tersebut tanpa perlu menghabiskan banyak waktu untuk menikmati fresh coffee hanya pada satu tempat saja. Hal tersebut tentu membuat kopi kekinian sangat mudah diterima oleh kawula muda, dimana itu serupa pada survei sederhana yang diteliti oleh IDN. Times bahwa sebanyak $74 \%$ adalah responden dengan rentang usia 18-28 tahun dengan 35,5\% penikmat kopi kekinian adalah mahasiswa. ${ }^{9}$ Para mahasiswa memang seringkali menggunakan kopi kekinian sebagai peneman dalam mengerjakan tugas dan memanfaatkan wifi yang disediakan kedai kopi, sebagai peneman saat galau atau sebagai peneman berbincang bersama teman (hangout) maupun hanya sekedar untuk mengikuti trend budaya ngopi kekinian yang sedang banyak digandrungi. Di Surabaya sendiri terdapat beberapa kedai kopi atau kafe kekinian yang tidak memiliki kejelasan kehalalan produk maupun gerainya serta terdapat penggunaan bahan rum, irish cream ataupun baileys pada produknya.

\footnotetext{
${ }^{6}$ Menteri Agama Republik Indonesia, Peraturan Menteri Agama (PMA) No.26 Tahun 2019 “Tentang Penyelenggaraan Jaminan Produk Halal” (2019).

7 Danang Sugianto, “Hasil Riset: Kedai Kopi Di RI Bertambah 2.000 Dalam 3 Tahun.," Detik Finance.com, 2019, https:/ / finance.detik.com/berita-ekonomi-bisnis/d-4826275/hasil-riset-kedai-kopi-diri-bertambah-2000-dalam-3-tahun.

${ }^{8}$ BPS Jawa Timur, “Jumlah Perguruan Tinggi, Mahasiswa Dan Tenaga Edukatif (Negeri Dan Swasta Di Bawah Kemetrian Riset, Teknologi Dan Pendidikan Menurut Kabupaten/ Kota Di Jawa Timur Tahun 2018/ 2019," 2019, https://jatim.bps.go.id/statictable/2019/10/09/1658/jumlah-perguruan-tinggimahasiswa-dan-tenaga-edukatif-negeri-dan-swasta-di-bawah-kementrian-riset-teknologi-dan-pendidikanmenurut-kabupaten-kota-di-jawa-timur-2018-2019-.html.
}

9 Putriana Cahya, “Tren Kopi Susu Kekinian, Akankah Segera Berlalu?," IDN.Times, 2019, https://jabar.idntimes.com/news/indonesia/putriana-cahya/tren-kopi-susu-kekinian-regional-jabar/full. 
Tingginya jumlah kedai kopi dan penikmat kopi di Indonesia menunjukkan jika minat beli pada kopi kekinian sangatlah tinggi, namun ini tentu saja mengharuskan umat islam perlu untuk melakukan berbagai pertimbangan serta berhati-hati sebelum memutuskan minatnya untuk mengkonsumsi suatu produk. Minat beli sendiri didefinisikan sebagai sebuah respon atas rangsangan yang muncul karena adanya ketertarikan guna mencoba produk, sehingga nantinya akan muncul keinginan untuk melakukan pembelian. ${ }^{10}$ Minat sendiri bisa berdampak pada perilaku maupun sikap dengan cukup besar pada sisi psikologisnya. ${ }^{11}$ Maka dari itu minat beli termasuk kedalam salah satu proses pengambilan keputusan pembelian pada suatu produk baik yang diinginkan maupun dibutuhkan. ${ }^{12}$

Dalam proses menentukan minat beli sendiri seseorang akan memiliki beragam pertimbangan yang diperhatikan sebelum menentukan minatnya pada suatu produk, salah satunya terdapat aspek agama yang memang harus diataati oleh semua umatnya apapun perintah maupun larangannya. Bagi pemeluk agama Islam sendiri terdapat perintah mengenai salah satu ketentuan dalam kegiatan konsumsi yang dilakukan yakni, sebagaimana sabda Allah pada QS. Al-Maidah (5): 88 berikut:

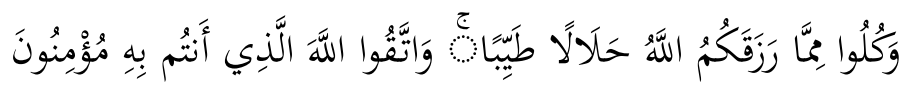

Artinya: "Dan makanlah makanan yang halal lagi baik dari apa yang Allah telah rezekikan kepadamu, dan bertakwalah kepada Allah yang beriman kepada-Nya"

Melalui firman Allah pada QS. Al-Maidah (5): 88 dapat diketahui jika umat Islam hendaklah harus melakukan konsumsi pada minuman dan makanan halal lagi baik bagi tubuh, sehingga diharapkan jika perintah tersebut dijalankan oleh umat Islam maka tubuhnya dapat terselamatkan dari sesuatu yang tidak dikehendaki selayaknya kecanduan, sakit, hilang akal, dan sebagainya. Maka dari itu dalam menentukan minat terutama pada suatu produk yang dikonsumsi (dicerna) oleh tubuh diperlukan kehati-hatian yang ekstra terutama agar tidak melanggar aturan agama yang dianutnya.

Dalam menentukan minat beli pada produk halal itu sendiri hendaknya seseorang perlu untuk dibekali oleh pengetahuan dan religiusitas. Adapun keterkaitan antara pengetahuan terhadap minat beli itu sendiri dapat dilihat melalui penelitian yang dilakukan oleh Vristiyana, menunjukkan jika pengetahuan berpengaruh secara positif dan signifikan terhadap minat beli, sehingga jika pengetahuan yang dimiliki seseorang tinggi maka minat beli terhadap makanan atau minuman halal juga akan tinggi. ${ }^{13}$ Begitupula dengan

\footnotetext{
10 Ruri Putri Utami and Hendra Saputra, "Pengaruh Harga Dan Kualitas Produk Terhadap Minat Beli Sayuran Organik Di Pasar Utami, Ruri Putri Saputra, Hendrasambas Medan 1)," Jurnal NLAGAWAN 6, no. 2 (2017): 44-53.

${ }^{11}$ Sunarti Maghfiroh As'alul, Zainul Arifin, "Pengaruh Citra Merek Terhadap Minat Beli Dan Keputusan Pembelian,” Jurnal Administrasi Bisnis (JAB) 40, no. 1 (2016): 132-40.

12 Karina Indah Rohmatun and Citra Kusuma Dewi, "Pengaruh Pengetahuan Dan Religiusitas Terhadap Niat Beli Pada Kosmetik Halal Melalui Sikap,” Jurnal Ecodemica 1, no. 1 (2017): 27-35.

13 Visca Mirza Vristiyana, "Pengaruh Religiusitas Dan Pengetahuan Produk Halal Terhadap Penilaian Produk Halal Dan Minat Pembelian Produk Halal,” EKOBIS 20, no. 1 (2019): 85-100.
} 
penelitian dari Briliana dan Mursito yang mengungkapkan jika pengetahuan merupakan salah satu anteseden penting yang memengaruhi minat beli. ${ }^{14}$

Sedangkan untuk keterkaitan religiusitas atas minat beli bisa diketahui melalui penelitian milik Mutmainah yang menunjukkan apabila religiusitas berdampak positif juga signifikan pada purchase intention makanan halal, ${ }^{15}$ dan pada penelitian milik Hermanto terbukti jika religiusitas berpengaruh secara langsung terhadap minat pembelian produk makanan halal. ${ }^{16}$

Dengan melihat adanya saling keterkaitan antara pengetahuan, religiusitas dan minat beli maka penulis tertarik guna mencari tahu bagaimana pengaruh dari pengetahuan juga religiusitas pada minat beli konsumen pada kopi kekinian halal dikalangan mahasiswa muslim yang menempuh pendidikan di wilayah Surabaya, dikarenakan saat ini kopi kekinian sangat digemari oleh beragam kalangan terutama kawula muda, namun hal tersebut tidak diimbangi dengan banyaknya jumlah kedai kopi kekinian halal yang ada di wilayah Surabaya.

\section{Landasan Teori}

\section{Minat Beli}

Dalam Kamus Besar Bahasa Indonesia minat diartikan sebagai sebuah perhatian, kesukaan maupun kecenderungan hati terhadap sesuatu atau keinginan. ${ }^{17}$ Minat merupakan salah satu aspek yang berpengaruh cukup besar pada sikap perilaku. ${ }^{18}$

Maka dari itu minat beli diartikan sebagai sebuah respon. dari rangsangan yang timbul dari rasa ketertarikan untuk mencoba sebuah produk, sehingga akan ada rasa keinginan konsumen melakukan pembelian. ${ }^{19}$ Purchase intention bisa dikatakan juga dengan pemikiran nyata dari refleksi atas perencanaan pembelian pada sejumlah merk yang ada pada saat tertentu. ${ }^{20}$ Sehingga purchase intention ialah salah satu jalan

\footnotetext{
14 Vita Briliana and Nurwanti Mursito, "Exploring Antecedents and Consequences of Indonesian Muslim Youths' Attitude towards Halal Cosmetic Products: A Case Study in Jakarta," Asia Pacific Management Review 22, no. 4 (2017): 176-84, https://doi.org/10.1016/j.apmrv.2017.07.012.

${ }^{15} \mathrm{Lu}$ Mutmainah, "Halal Certification, and Food Ingredients on Purchase Intention of Halal Food The Role of Religiosity, Halal Awareness, Halal Certification, and Food Ingredients on The Purchase Role of Religiosity , Awareness , Intention Halal of Halal Food The Role," (HTIFAZ) Journal of Islamic Economics, Finance and Banking 1, no. 1 dan 2 (2018).

${ }^{16}$ Edwin Hermanto, "The Analysis of Religiosity and Country of Origin Influence Towards Purchase Intention with Consumer Attitudes as The Intervening Variable in KFC Pandanaran Semarang (Case Study in FE UNISSULA'S Students)," International Jurnal of Islamic Business Ethics (IJIBE) 3, no. 2 (2018): 473-82.

${ }^{17}$ KBBI, “Kamus Besar Bahasa Indonesia (Online),” 2020, https://kbbi.web.id/minat.

18 Maghfiroh As'alul, Zainul Arifin, "Pengaruh Citra Merek Terhadap Minat Beli Dan Keputusan Pembelian."

${ }^{19}$ Utami and Saputra, "Pengaruh Harga Dan Kualitas Produk Terhadap Minat Beli Sayuran Organik Di Pasar Utami, Ruri Putri Saputra, Hendrasambas Medan 1).”

20 Tri Asih Hidayati, Suharyono, and Dahlan Fanani, "Pengaruh Citra Merek Terhadap Minat Beli Dan Keputusan Pembelian Konsumen,” Administrasi Bisnis (JAB) 2 No. 1 (2013).
} 
dalam penentuan akhir pembelian dimana itu diambil oleh konsumen untuk komoditi yang diinginkan maupun dibutuhkannya. ${ }^{21}$

Dalam berminat terhadap sebuah produk yang akan dikonsumsi hendaknya sebagai orang beragama sangat perlu untuk melakukan berbagai pertimbangan dan berhatihati dalam memilih. Seperti halnya sesuai dengan QS. Al-Maidah (5):88 sebagai berikut:

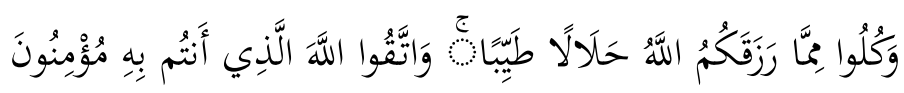

Artinya: "Dan makanlah makanan yang halal lagi baik dari apa yang Allab telah rezekikan kepadamu, dan bertakwalah kepada Allah yang beriman kepada-Nya"

Berdasarkan QS. Al-Maidah (5):88, jelas bahwa Tuhan mengutus umatnya untuk mengkonsumsi segala hal yang disukai dan sesuai selera namun hendaklah sesuatu itu halal dan bersifat baik bagi tubuh, takutlah dan taatlah kepada Allah selama kalian beriman kepadanya. Dengan mengkonsumsi sesuatu yang halal lagi baik yang diyakini selaku suatu jalan guna bertakwa pada Allah jika dilaksanakan, maka sebelum menentukan minat pada suatu produk, aspek halal dan baik bagi tubuh sangatlah penting untuk dijadikan pertimbangan, agar saat telah memutuskan untuk melakaukan pembelian dapat memperoleh kepuasan yang maksimum baik dari sisi dunia maupun akhirat.

Dalam berminat tentunya terdapat hal-hal yang dapat mempengaruhinya seperti yang dikemukakan oleh Schiffman dan Kanuk yang diantaranya adalah, ${ }^{22}$ pengalaman pribadi dimna dari pengalaman pembelian terhadap suatu produk, dapat langsung dijadikan pondasi penilaian guna membentuk motivasi, presepsi, memori juga kepribadian sebagai stimulus untuk pembelajaran dalam memutuskan minat pembelian ulang ataupun minat pembelian pada produk sejenis. Kemudian pengaruh keluarga dan teman, melalui orang-orang terdekat kita akan lebih cenderung menjadi sumber pembentuk sikap konsumen, dimana melalui pengajaran nilai dasar maupun beragam keyakinan hidup. Sehingga hal tersebut tentu akan berpengaruh terhadap minat beli terutama jika hal tersebut bersifat referensi dari mereka. Lalu pemasaran langsung, dimana pada bagian ini minat pembelian konsumen dapat terpengaruh melalui penawaran- penawaran dari sebuah komoditas yang diketahui menunjukkan value yang melampaui komoditas lain terutama jika komoditas itu bisa menjadi pemenuhan atas kebutuhan dan keinginan serta memberikan perhatian besar bagi setiap konsumen sesuai dengan segmennya. Kemudian yang terakhir adalah media massa untuk bagian ini minat pembelian konsumen dapat terpengaruh dari beragam iklan maupun gagasan produk yang menggiurkan juga informatif sehingga konsumen terbentuk sikap untuk memutuskan berminat untuk melakukan pembelian.

Selain terdapat hal-hal yang dapat mempengaruhi seseorang berminat pada suatu produk, tentunya ada empat indikator yang dapat menjadi penilai dari minat beli pada konsumen, adapun diantaranya seperti yang dikemukakan oleh Lucas dan Britt $^{23}$ yakni yang pertama adalah perhatian dimana merupakan bentuk pengamatan

\footnotetext{
${ }^{21}$ Rohmatun and Dewi, "Pengaruh Pengetahuan Dan Religiusitas Terhadap Niat Beli Pada Kosmetik Halal Melalui Sikap."

22 Beslie Bazar Schiffman, Leon G dan Kanuk, Perilaku Konsumen, Ketujuh (PT. Indes, 2008).

${ }^{23}$ S. H Lucas, D. B dan Britt, Advertising Psychology and Research (New York: Mc Graw- Hill, 1950).
} 
yang dilakukan oleh konsumen secara terpusat pada suatu produk yang dianggapnya menarik, sehingga hal tersebut menggambarkan refleksi dari minat konsumen untuk melakukan pembelian. Kedua ketertarikan, saat setelah adanya perhatian maka akan muncul bentuk ketertarikan yang berupa dorongan untuk memperhatikan secara lebih, sehingga timbul usaha dari konsumen untuk mendekati produk yang diminati. Ketiga keinginan, dimana melalui ketertarikan, pada diri konsumen akan muncul rasa keinginan dengan dorongan untuk dapat lebih mengetahui juga memiliki produk yang menarik minatnya. Keempat keyakinan, yang pada akhirnya muncul rasa keyakinan pada diri konsumen terhadap segala aspek produk yang diminatinya, sehingga konsumen berada pada titik merasa dapat melakukan pembelian pada produk tersebut.

\section{Pengetahuan}

Pengetahuan dalam Kamus Besar Bahasa Indonesia dapat diartikan sebagai sesuatu yang diketahui, yakni berupa kepandaian yang berkenaan dengan suatu hal. ${ }^{24}$ Begitupula menurut Sjamsuri yang mengungkapkan jika pengetahuan pada hakekatnya adalah berupa segenap hal yang diketahui mengenai suatu objek, dimana termasuk didalamnya adalah ilmu. ${ }^{25}$ Notoadmodjo juga mengungkapkan hal yang tidak jauh berbeda jika pengetahuan adalah hasil dari "tahu" dimana hal tersebut diperoleh setelah seseorang melakukan pengindraan pada sebuah objek, baik diperoleh dengan pengalaman langsung maupun pengalaman orang lain guna menyelesaikan masalah yang ada. ${ }^{26}$

Islam sendiri terdapat al-Qur'an sebagai pedoman yang digunakan di hidup umatnya, dimana didalamnnya terdapat banyak hal tentang ilmu pengetahuan yang berupa petunjuk bahkan perintah agar manusia menggunakan akalnya untuk terus melakukan observasi pada alam ciptaanya. Sesuai dengan firman Allah pada QS. AlIsra' (17: 36) yang berbunyi:

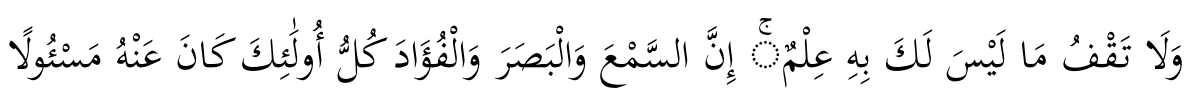

Artinya: "Dan janganlah kamu mengikuti apa yang kamu tidak mempunyai pengetahuan tentangnya. Sesunggubnya pendengaran, pengelihatan dan hati, semuanya itu akan diminta pertanggungjawabanya"

Maka dari itu sangatlah penting bagi setiap manusia untuk memiliki pengetahuan guna menjadikannya sebagai penuntun dalam menjalani hidup maupun menyelesaikan masalah. Setiap pengetahuan yang dimiliki seseorang memang memiliki fungsinya masing- masing seperti halnya pengetahuan mengenai suatu produk agar sebelum memutuskan untuk melakukan pembelian, seorang konsumen dengan cerdas dapat memilah dan memilih suatu produk yang sesuai ketentuan, keinginan, kebutuhan juga dapat memenuhi kepuasannya.

Dalam pengetahuan mengenai suatu produk sendiri terdapat beberapa hal yang harus dilakukan yakni seperti mencari informasi mengenai kulaitas, manfaat maupun

\footnotetext{
${ }^{24}$ KBBI, “Kamus Besar Bahasa Indonesia (Online)," 2020, https://kbbi.web.id/pengetahuan.

${ }^{25}$ Sjamsuri, Pengantar Teori Pengetahuan (Jakarta: Departemen Pendidikan dan Kebudayaan Direktorat Jendral Pendidikan Tinggi, 1989).

${ }^{26}$ Soekidjo Notoadmodjo, Metodologi Penelitian Kesehatan (Jakarta: Rineka Cipta, 2012).
} 
karakteristik pada bahan atau pernyataan halal pada kemasan, agar saat memutuskan melakukan pembelian seorang konsumen terutama yang beragama islam dapat memperoleh kepuasan tertinggi yang diharapkannya dari produk, juga ketenangan dalam mengkonsumsi produk yang berpadan pada arahan Allah pada Al-Qur'an tentang keharusan untuk memiliki pengetahuan mengenai bahan yang tergolong halal ataupun tidak. Adapun salah satu firman Allah yang mengharuskan umatnya untuk tahu bahwa terdapat salah satu bahan yang diharamkan untuk dikonsumsi yakni pada QS. Al-Baqarah (2): 219 sebagai berikut:

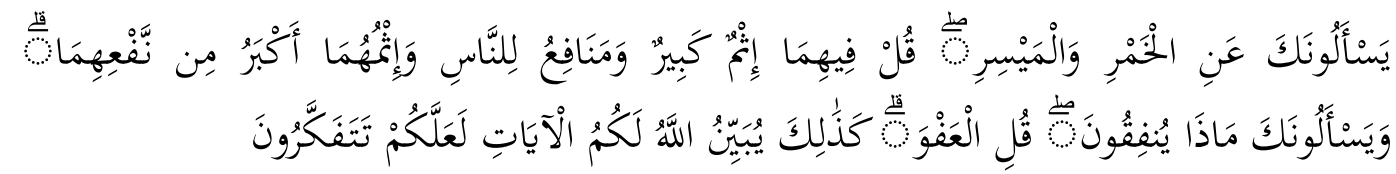

Artinya: "Mereka bertanya kepadamu tentang khamr dan judi. Katakanlah: "Pada keduanya terdapat dosa yang besar dan beberapa manfaat bagi manusia, tetapi dosa keduanya lebih besar dari manfaatnya". Dan mereka bertanya kepadamu apa yang mereka nafkahkan. Katakanlab: "Yang lebih dari keperluan". Demikianlah Allah menerangkan ayat-ayat-Nya kepadamu supaya kamu berfikir."

Menurut tafsir Al-Maraghi, tentang QS. Al-Baqarah (2): 219 dijelaskan bahwasanya khamr adalah segala sesuatu yang memabukkan menurut mazhab Imam Syafi'i, dimana hal tersebut sesuai dengan hadits riwayat Abu Daud dan Tirmidzi yang meriwayatkan sabda rasulluallah, bahwa "setiap yang memabukkan adalah khamr" selain itu Imam Syafi'i menjelaskan jika khamr tidak dibuat hanya dari olahan beragam jenis anggur, namun juga dari perasan lainnya seperti kurma, madu, gandum, dll. Selain khamr itu diharamkan dalam islam, sejatinya khamr memang memiliki beberapa bahaya terhadap kehidupan jika dikonsumsi, diantarnya yaitu bahaya bagi kesehatan, yakni dapat merusak pencernaan makanan, menghilangkan nafsu makan, kedua biji mata tampak besar, penyakit jantung, kandung kemih dan paru-paru, dsb. Kemudian terdapat bahaya bagi akal, dimana khamr dapat melemahkan daya piker seseorang atau bahkan dapat membuat seseorang menjadi gila. Selanjutnya bahaya terhadap agama, dimana khamr dapat merusak ibadah. Dan masih banyak lagi bahaya yang dapat ditimbulkan dari mengkonsumsi khamr. ${ }^{27}$

Maka dari itu memilah makanan dan minuman yang dikonsumsi haruslah dapat sesuai dengan aturan agama maupun kesehatan, guna saat memiliki pengetahuan dapat dimanfaatkan untuk membantu dalam memutuskan suatu minat pada produk, sehingga saat dilakukan pembelian dapat memperoleh kepuasan yang maksimum baik dari sisi dunia maupun akhirat.

Dalam tingkatannya sendiri pengetahuan memiliki beberapa jenjang, diantaranya sebagai berikut sesuai dengan yang dikemukakan oleh Notoadmodjo, yang juga akan menjadi indikator dalam penelitian ini, ${ }^{28}$ dimana pada tingkat pertama adalah tahu (know) yang dapat diartikan sebagai pengingat atas satu entitas yang pernah sebelumnya dikaji, yang terbilang didalamnya mengenali lagi sesuatu yang sudah dikaji juga rangsangan yang telah diterima, maka dari itu ini merupakan tingkatan yang paling rendah. Kemudian pada tingkat kedua yaitu memahami (comprehension),

\footnotetext{
${ }^{27}$ Ahmad Mustafa Al-Maragi, Tafsir Al-Maragi, Juz 2 (Semarang: PT. Karya Toha Putra, 1993).

${ }^{28}$ Soekidjo Notoadmodjo, Metodologi Penelitian Kesehatan (Jakarta: Rineka Cipta, 2007).
} 
pada pengetahuan tingkat ini menunjukkan sesorang yang dapat dengan benar menjelaskan atas objek yang diketahui dan dapat menginterpretasikannya. Orang yang termasuk dalam kategori ini diharuskan untuk bisa memberikan penjelasan, memberikan contoh, memberikan kesimpulan, dsb atas sesuatu saat telah dikaji. Tingkatan ketiga terdapat aplikasi (Aplication), dimana orang yang berada pada tingkat ini menunjukkan jika dirinya telah mampu membawa sesuatu yang telah dipelajari pada situasi nyata, yang termasuk didalamnya adalah untuk para pengguna hukum, rumus, metode, prinsip, dsb. Dimana dapat dicontohkan dengan pengunaan prinsip pemecahan masalah terhadap pemecahan masalah menentukan minat pada suatu produk tertentu.

Adapun berdasarkan penelitian terdahulu, seringkali pengetahuan yang dimiliki seseorang akan berpengaruh terhadap minat belinya terhadap suatu produk, dimana tingkatannya pun akan dapat dilihat melalui minat beli yang ditunjukkan oleh seorang konsumen itu sendiri dalam memilah dan memilih suatu produk. Adapun berdasarkan penelitian terdahulu milik Vristiyana menunjukkan jika pengetahuan berpengaruh secara positif dan signifikan terhadap minat beli makanan dan minuman halal. ${ }^{29}$ Penelitian yang diteliti Briliana dan Mursito juga membuktikan jika knowledge merupakan anteseden penting dalam mempengaruhi minat beli produk halal, dimana pengetahuan dapat ditingkatkan melalui rekomendasi kelompok maupun iklan dan display toko. ${ }^{30}$

\section{Religiusitas}

Menurut Kamus Besar Bahasa Indonesia religiusitas merupakan bentuk ketaatan atau pengabdian pada agama. ${ }^{31}$ Religiusitas sendiri berasal dari kata religi yang memiliki makna agama. Seseorang dapat dikatakan religius jika mereka berusaha untuk semakin memperdalam pemahamannya mengenai hidup maupun kehidupan dari sebelumnya. Religiusitas bisa dikatakan juga dengan bentuk desakan dari diri manusia guna bersikap maupun bertingkah laku sesuai kadar ketaatan pada agamanya, religiusitas juga dapat diartikan sebagai suatu gabungan lengkap dari pengetahuan, perasaan dan tindakan yang berbasis agama pada diri setiap orang, dimana hal tersebut saling berhubungan erat sehingga dapat menjadi alasan dari proses, sebab dan pembentukan religiusitas seseorang yang juga dipengaruhi oleh hasil belajar dari interaksi dan pengalaman. ${ }^{32}$ Dalam Al-Qur'an sendiri Allah sudah menginstruksikan umatnya guna senantiasa bersikap religius dalam hidupnya, dimana berpadan pada sabda Allah pada QS. Al-Baqarah (2):208:

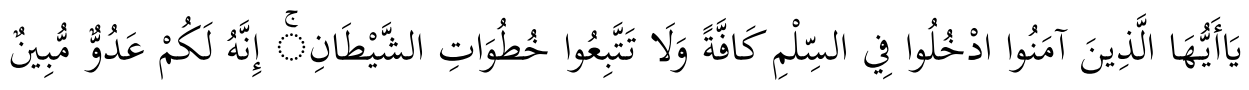

Artinya: "Hai orang-orang yang beriman, masuklah kamu kedalam islam keseluruban, dan janganlah kamu turut langkah- langkah syaitan. Sesunggubnya syaitan itu musuh yang nyata bagimu."

\footnotetext{
${ }^{29}$ Vristiyana, "Pengaruh Religiusitas Dan Pengetahuan Produk Halal Terhadap Penilaian Produk Halal Dan Minat Pembelian Produk Halal."

30 Briliana and Mursito, "Exploring Antecedents and Consequences of Indonesian Muslim Youths' Attitude towards Halal Cosmetic Products: A Case Study in Jakarta."

${ }^{31}$ KBBI, “Kamus Besar Bahasa Indonesia (Online),” 2020, https://kbbi.web.id/religius.

32 Jalaluddin, Psikologi Agama (Jakarta: Raja Grafindo Persada, 2009).
} 
Dalam QS. Al-Baqarah (2):208 telah dijelaskan bahwa kita sebagai umat islam hendaknya bersikap religius, yakni dengan menjalankan ketentuan-ketentuan islam secara keseluruhan, serta menjauhi larangannya.

Religiusitas sendiri dapat diwujudkan pada setiap sisi kehidupan, dengan kata lain religiusitas tidak hanya dapat dilihat pada saat seseorang melaksanakan ibadah namun ada pula pada aksi lain yang dibawa dengan daya akhir baik pada aksi terlihat mata maupun aksi terjadi dalam hati seseorang, seperti halnya yang tercermin pada penggunaan pakain sehari-hari dengan menggunakan baju koko, kopiyah juga sarung. ${ }^{33}$

Selain religiusitas dapat tercerminkan melalui penggunaan pakaian, religiusitas juga dapat dipraktikkan dalam kegiatan keseharian yang lain, yakni dalam hal sederhana seperti memilih dan memilah makanan juga minuman yang halal lagi baik bagi jiwa dan raga saat berada dimanapun. Hal itu sendiri berpadan terhadap sabda Allah pada QS. Al-Baqarah (2):168:

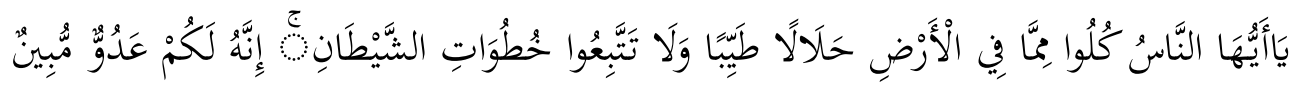

Artinya: "Hai sekalian manusia, makanlah yang halal lagi baik dari apa yang terdapat di bumi, dan janganlah kamu mengikuti langkah-langkah setan, karena sesunggubnya setan itu adalah musub yang nyata bagimu."

Tafsir Al-Maraghi memperlihatkan jika QS. Al-Baqarah (2):168 membahas tentang perintah Allah bagi hambanya guna melakukan konsumsi pada sesuatu yang bersifat halal lagi baik, dan tidaklah hal yang diharamkan untuk dikonsumsi baik dari segi zatnya yang haram 'arid, selain itu juga memerintahkan agar umatnya tidak mengikuti jejak setan yang sering memprovokasi manusia guna melalui jalan tercela dan keji juga menyesatkan serta sebagai awal mula dari suatu niat buruk juga tidak baik yang mendesak melakukan perilaku tercela dan dosa. ${ }^{34}$

Adapun religiusitas terbagi kedalam 5 dimensi yang diungkap oleh Ancok dan Suroso, sebagaimana sesuai dengan rumusan Glock dan Stark, yakni, ${ }^{35}$ yang pertama dimensi keyakinan dimana terdapat seperangkat kepercayaan pada setiap agama yang nantinya diharapkan bagi para penganutnya untuk taat, disitulah dimensi ini dibahas pada letak pengharapan-pengharapan teologis seorang umat yang religius dengan mengakui dan berpegang teguh pada doktrin-doktrin agamanya. Kedua dimensi praktik agama, untuk letak dimensi ini adalah pada bagian dimana seorang umat menunjukkan komitmennya pada agama yang dianut. Ketiga dimensi pengalaman pada dimensi ini terletak pada bagaimana pengalaman dalam menjalankan kegiatan keagamaan, kesan dan impresi yang dirasakan tiap individu umat maupun definisi yang dipercayai oleh kelompok keagamaan dalam memandang komunikasi yang beresensi ketuhanan walapun hanya dalam bentuk kecil. Keempat terdapat dimensi pengetahuan agama, dimensi ini terletak pada pengharapan dimana setidaknya bagi orang yang beriman ada sejumlah ilmu hal mendasar mengenai kitab suci, adat,

\footnotetext{
${ }^{33}$ F. N Ancok, D dan Suroso, Psikologi Islami: Solusi Islam Atas Problem-Problem Psikologi (Yogyakarta: Pustaka Pelajar, 1994).

34 Al-Maragi, Tafsir Al-Maragi.

35 Ancok, D dan Suroso, Psikologi Islami: Solusi Islam Atas Problem-Problem Psikologi.
} 
keyakinan, maupun budaya dalam keyakinannya. Kelima dimensi pengamalan yang terletak pada pengharapan agar umatnya dapat mengidentifikasi akibat atau konsekuensi yang mungkin timbul dari keyakinan, praktik, pengalaman dan pengetahuan dari aktivitas keagaamaan yang dijalani dari hari ke hari.

Adapun pada dasarnya religiusitas yang merupakan dorongan dalam diri yang dapat mencerminkan tingkat ketaatan seseorang yang dapat dijadikan sebagai gaya hidup, dimana agar implementasi dari kepatuhan pada agama lebih mudah untuk dilakukan, seperti halnya membiasakan diri untuk berminat pada produk-produk halal terutama yang telah bersertifikasi halal. Adapun pengaruh religiusitas pada minat beli dapat dilihat melalui hasil penelitian milik Mutmainah yang menunjukkan jika religiosity memberikan pengaruh positif dan signifikan pada purchase intention makanan halal. ${ }^{36}$ Begitupula dengan penelitian milik Hermanto yang membuktikan jika religiusitas berpengaruh secara langsung terhadap minat pembelian produk KFC di Pandanaran Semarang, dimana dikatakan jika religiusitas seseorang semakin baik maka minat pembelian pada produk KFC akan semakin menurun dikarenakan masih banyak konsumen yang meragukan kehalalan produknya, juga adanya isu mengenai dukungan dana yang diberikan KFC pada Israel atas masalahnya dengan Palestina. ${ }^{37}$

\section{Hipotesis Penelitian}

Berdasarkan beberapa uraian mengenai keterkaitan pengetahuan dan religiusitas terhadap minat beli dapat dibuat beberapa rumusan hipotesis untuk penelitian ini diantaranya:

a. $\mathrm{H}_{0}$ : Diduga pengetahuan konsumen kopi tidak berpengaruh secara positif dan signifikan terhadap minat belli kopi kekinian yang telah memiliki sertifikasi halal.

b. $\mathrm{H}_{1}$ : Diduga pengetahuan konsumen kopi berpengaruh secara positif dan signifikan terhadap minat beli kopi kekinian yang telah memiliki sertifikasi halal.

c. $\mathrm{H}_{0}$ : Diduga religiusitas konsumen kopi tidak berpengaruh secara positif dan signifikan terhadap minat beli kopi kekinian yang telah memiliki sertifikasi halal.

d. $\mathrm{H}_{2}$ : Diduga religiusitas konsumen kopi berpengaruh secara positif dan signifikan terhadap minat beli kopi kekinian yang telah memiliki sertifikasi halal.

e. $\mathrm{H}_{0}$ : Diduga pengetahuan dan religiusitas tidak berpengaruh secara simultan terhadap minat beli kopi kekinian yang telah memiliki sertifikasi halal.

f. $\mathrm{H}_{3}$ : Diduga pengetahuan dan religiusitas berpengaruh secara simultan terhadap minat beli kopi kekinian yang telah memiliki sertifikasi halal.

\section{Metode Penelitian}

Penelitian ini terhitung masuk kedalam penelitian jenis kuantitatif deskriptif, dimana data maupun informasi yang akan digunakan berwujud dalam bentuk angka dan akan terdapat

\footnotetext{
${ }^{36}$ Mutmainah, "Halal Certification, and Food Ingredients on Purchase Intention of Halal Food The Role of Religiosity, Halal Awareness, Halal Certification, and Food Ingredients on The Purchase Role of Religiosity , Awareness , Intention Halal of Halal Food The Role.”

${ }^{37}$ Hermanto, "The Analysis of Religiosity and Country of Origin Influence Towards Purchase Intention with Consumer Attitudes as The Intervening Variable in KFC Pandanaran Semarang (Case Study in FE UNISSULA'S Students).”
} 
penjelasan berupa analisis juga interpretasi dari data yang telah diolah. Selain itu penelitian ini tergolong pula kedalam penelitian asosiatif dikarenakan penulis ingin mencari tahu pengaruh dari knowledge dan religiosity pada purchase intention. Populasi yang termasuk pada penelitian ini ialah mahasiswa yang menempuh pendidikan di wilayah Surabaya yakni sebanyak 272.846 mahasiswa dari berbagai jurusan dan perguruan tinggi, dimana jumlah tersebut diperoleh dari data BPS Jawa Timur, ${ }^{38}$ yang kemudian sampel dalam penelitian ini diperoleh melalui perhitungan menggunakan rumus slovin berikut, dimana dengan ketentuan menggunakan tingkat kepercayaan untuk penelitian yakni sebesar 95\% dan perkiraan untuk proporsi yang digunakan adalah sebesar 0,5 :

$$
\begin{gathered}
n=\frac{N}{N(d)^{2}+1} \\
n=\frac{272.846}{272.846(0,1)^{2}+1}=99,96
\end{gathered}
$$

Sehingga total sampel yang diperlukan penelitian ini ialah sejumlah 99,96 mahasiswa atau jika dibulatkan menjadi 100 mahasiswa. Purposive sampling akan dipilih sebagai teknik untuk memperoleh sampel dan digunakan 4 pertimbangan tertentu, yakni diantaranya adalah responden yang merupakan mahasiswa muslim baik yang saat ini menjalani pendidikan tingkat S1, S2 maupun S3 di wilayah Surabaya, berusia minimal 18-64 tahun dan merupakan konsumen kafe yang berminat untuk membeli kopi kekinian bersertifikasi halal dengan persentase responden laki-laki sebanyak $20 \%$ dan perempuan sebanyak $80 \%$ dari jumlah seluruh mahasiswa yang terlibat dalam penelitian. Selain itu terdapat beberapa nama-nama kopi keknian yang dimasukkan kedalam kuisioner yang dapat dipilih responden lebih dari satu nama brand, dimana nama-nama brand tersebut merupakan beberapa nama yang sekiranya digemari dan memiliki popularitas dikalangan anak muda pecinta kopi kekinian di wilayah Surabaya serta berada pada kisaran harga jual di kelas menengah keatas namun masih dalam jangkauan harga yang dapat dibeli oleh para mahasiswa baik yang kos maupun tidak. Data akan diperoleh melalui hasil dari penyebaran kuisioner secara online memakai $g$-form, dimana model akan digunakan dalam angket penelitian ini berupa daftar pernyataan yang menggunakan skala likert sebagai penentu skala sikap untuk responden dalam memilih jawaban, adapun pilihan jawaban yang akan digunakan adalah dari skala 1 yang menunjukkan jika responden memberikan jawaban yang memiliki tingkat kesesuaian dengan pertanyaan yang tinggi, hingga penggunaan skala 5 yang berarti jika kesesuaian jawaban responden berada pada tingkat yang sangat rendah dengan pertanyaan. Untuk Teknik analisis data dimana akan dipakai pada peneltian ini ialah analisis regresi linear berganda, dimana teknik ini dipakai guna menganalisis keterkaitan antara variabel dependen dengan variabel independen. Adapun langkah yang perlu dilakukan untuk menganalisis data yaitu dimulai dengan uji instrument penelitian yang terdiri dari uji validitas dan uji reliabilitas, kemudian dilanjut dengan uji regresi linear berganda dimana dalam penelitian ini dirmuskan dengan model:

$\mathrm{Y}=\alpha+\beta_{1} \mathrm{X}_{1}+\beta_{2} \mathrm{X}_{2}+\mathrm{e}$

Keterangan:

Y : variabel terikat

\footnotetext{
${ }^{38}$ Jawa Timur, "Jumlah Perguruan Tinggi, Mahasiswa Dan Tenaga Edukatif (Negeri Dan Swasta Di Bawah Kemetrian Riset, Teknologi Dan Pendidikan Menurut Kabupaten/ Kota Di Jawa Timur Tahun 2018/ 2019."
} 


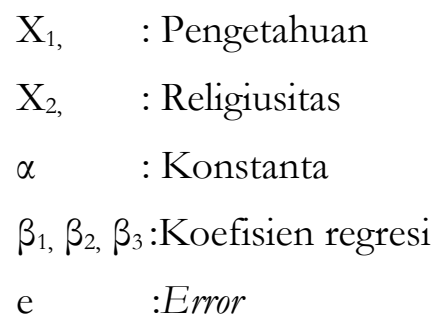

Adapun sebagai tahap terakhir yang perlu dilakakukan yaitu uji hipotesis dan terdiri atas uji $\mathrm{T}$, uji $\mathrm{F}$, dan uji koefisien determinan.

\section{Hasil Penelitian dan Pembahasan}

\section{Karakteristik Responden}

Penelitian ini sudah ditetapkan bahwa sampel yang dipakai ialah sejumlah 100 responden dari jumlah populasi penelitian, adapula dimana penggunaan purposive sampling pada penelitian ini guna menentukan jika sampel yang dipakai haruslah seorang mahasiswa yang sedang menempuh pendidikan di wilayah Surabaya, berusia minimal 18 tahun dan merupakan seorang yang beragama islam atau muslim. Maka dari itu perolehan atas pembagian kuisioner penelitian ini didapatkan dengan idiosinkrasi responden yang 100\% merupakan seorang mahasiswa yang menempuh pendidikan diwilayah Surabaya dan merupakan seorang muslim serta dengan ketentuan reponden laki-laki sebanyak 20\% dan perempuan sebanyak $80 \%$ dari 100 responden yang terlibat, sedangkan untuk karakteristik responden yang lebih jelas dapat diketahui pada tabel berikut.

Tabel 1. Karakteristik Responden

\begin{tabular}{cccc}
\hline Karakteristik & Kriteria & Jumlah & Prosentase \\
\hline \multirow{3}{*}{ Usia } & $18-24$ & 95 & $95 \%$ \\
& $25-34$ & 5 & $5 \%$ \\
& $35-44$ & 0 & $0 \%$ \\
& $45-54$ & 0 & $0 \%$ \\
Asal & $55-64$ & 0 & $0 \%$ \\
Perguruan & UNITOMO & 2 & $2 \%$ \\
Tinggi & UINSA & 11 & $11 \%$ \\
& UNAIR & 8 & $8 \%$ \\
& UNESA & 60 & $60 \%$ \\
& ITS & 1 & $1 \%$ \\
& UBHARA & 2 & $2 \%$ \\
& UERBANAS & 1 & $1 \%$ \\
& UNSURI & 9 & $9 \%$
\end{tabular}




\begin{tabular}{ccc} 
UNUSA & 1 & $1 \%$ \\
STIE MAHARDIKA & 4 & $4 \%$ \\
UT & 1 & $1 \%$ \\
\hline
\end{tabular}

Sumber: Diolah penulis (2020)

Pada tabel 1 tersebut dapat diketahui jika, sebagian besar responden dari penelitian ini merupakan seorang perempuan dimana hal tersebut ditunjukkan dengan jumlahnya yang sebanyak $80 \%$ dari jumlah sampel penelitian ini, sedangkan sisanya sebanyak 20\% adalah responden laki- laki. Selain itu penelitian ini juga di dominasi oleh responden dengan frekuensi umur 18-24 tahun yakni sebesar 95\% dan untuk 5\% yang tersisa ditempati oleh para responden dengan umur 25-34 tahun.

Seperti yang diketahui jika penelitian ini memakai sampel mahasiswa yang menempuh pendidikan di wilayah Surabaya maka perguruan tinggi dari responden pada penelitian ini juga bersumber pada perguruan tingkat tinggi di wilayah Surabaya, dimana dengan berdasarkan data yang diperlah untuk asal perguruan tinggi pada urutan pertama didominasi oleh responden Universitas Negeri Surabaya dengan persentase $60 \%$ dari jumlah sampel penelitian, kemudian diikuti oleh Universitas Islam Negeri Surabaya dengan 11\% responden, selanjutnya dengan 9\% jumlah responden diperoleh dari Universitas Sunan Giri Surabaya, dan kemudian di ikuti dengan perbedaan 1\% dari Universitas Sunan Giri Surabaya yakni sebesar 8\% responden penelitian ini adaah dari Universitas Negeri Airlangga, untuk sejumlah 4\%pada penelitian ini ditempati oleh responden dari Sekolah tinggi Ilmu Ekonomi Mahardika Surabaya dan 2\% lainnya pada penelitian ini respondennya berasal dari Universitas Bhayangkara Surabaya dan Universitas Dr. Soetomo, sedangkan dengan sejumlah 1\% lainnya dipenuhi oleh responden yang berasal dari Institut Teknologi Surabaya, Sekolah Tinggi Ilmu Ekonomi Perbankan Surabaya, Universitas Nahdlatul Ulama Surabaya dan terakhir dari Universitas Terbuka Surabaya.

\section{Variabel Pengetahuan}

Variabel pengetahuan yang digunakan pada penelitian ini menggunakan sebanyak 3 indikator sebagai pengukurnya yaitu tahu, memahami dan aplikasi, dimana untuk penjelasannya dapat dilihat pada landasan teori mengenai pengetahuan. Adapun 11 item pernyataan telah digunakan sebagai representasi dari 3 indikator tersebut, berikut merupakan perseberan dari hasil jawaban responden dari kuisioner yang telah disebarkan untuk bagian variabel pengetahuan:

Tabel 2. Persebaran Hasil Jawaban Responden pada Variabel Pengetahuan

\begin{tabular}{cccc}
\hline No. & Kriteria Jawaban & Jumlah & Persentase \\
\hline 1 & Sangat Setuju & 355 & $32 \%$ \\
2 & Setuju & 397 & $36 \%$ \\
3 & Ragu - Ragu & 225 & $21 \%$ \\
4 & Tidak Setuju & 88 & $8 \%$ \\
5 & Sangat Tidak Setuju & 35 & $3 \%$ \\
\hline
\end{tabular}

Sumber: Diolah penulis (2020) 
Pada tabel 2 dapat dilihat bahwa hasil jawaban responden pada item pernyatan variabel pengetahuan sebanyak 68\% menunjukkan sikap dengan reaksi postif atas pernyatan yang disuguhkan, adapun sebanyak 21\% menunjukkan sikap tidak pasti atau ragu-ragu dengan indikator pada variabel pengetahuan ini, sedangkan untuk $11 \%$ yang tersisa jawaban dari responden menunjukkan sikap dengan reaksi negatif atas pernyataan penelitian ini. Sehingga dapat diketahui bahwa berdasarkan jawaban responden menunjukkan jika sebagian besar responden memiliki pengetahuan dasar mengenai produk halal.

\section{Variabel Religiusitas}

Variabel religiusitas untuk penelitian ini diukur menggunakan 5 indikator diantaranya adalah kayakinan, praktik agama, pengalaman, pengetahuan agama dan pengamalan, adapun untuk penjelasannya dapat dilihat pada landsan teori mengenai religiusitas. Adapula kelima indikator tersebut diwakilkan dengan sejumlah 12 item pernyataan, berikut persebaran dari jawaban responden atas pernyataan pada bagian variabel religiusitas:

Tabel 3. Persebaran Hasil Jawaban Responden pada Variabel Religiusitas

\begin{tabular}{cccc}
\hline No. & Kriteria Jawaban & Jumlah & Persentase \\
\hline 1 & Sangat Setuju & 885 & $73 \%$ \\
2 & Setuju & 251 & $20 \%$ \\
3 & Ragu-Ragu & 56 & $7 \%$ \\
4 & Tidak Setuju & 6 & $1 \%$ \\
5 & Sangat Tidak Setuju & 2 & $0 \%$ \\
\hline
\end{tabular}

Sumber: Diolah penulis (2020)

Tabel 3 menunjukkan jika 93\% diantara jawaban responden terletak pada bagian sangat setuju dan setuju, dimana hal tersebut membuktikan jika responden penelitian ini menunjukkan sikap positif terhadap indikator yang digunakan pada variabel religiusitas ini. Sedangkan untuk $7 \%$ dan $1 \%$ yang tersisa menunjukkan reaksi tidap pasti atau ragu-ragu dan reaksi negatif atas pernyataan yang disuguhkan pada kuisioner yang telah disebarkan. Sehingga bisa diambil kesimpulan, sejumlah besar responden telah mempunyai dan menerapkan religiusitas secara sangat baik di kehidupannya.

\section{Variabel Minat Beli}

Variabel purchase intension ini terdapat sebanyak empat indikator yaitu perhatian, ketertarikan, keinginana dan keyakinan yang digunkan sebagai pengukurnya dan dapat dilihat melalui penjelasan pada bagian landasan teori menganai minat beli, adapun sebanyak 6 item pernyataan digunakan untuk mewakili 4 indikator tersebut. Berikut terdapat penjabaran atas jawaban yang telah diberikan responden untuk bagian variabel minat beli dari kuisioner penelitian ini: 
Tabel 4. Persebaran Hasil Jawaban Responden pada Variabel Minat Beli

\begin{tabular}{cccc}
\hline No. & Kriteria Jawaban & Jumlah & Persentase \\
\hline 1 & Sangat Setuju & 144 & $24 \%$ \\
2 & Setuju & 203 & $34 \%$ \\
3 & Ragu-Ragu & 165 & $27 \%$ \\
4 & Tidak Setuju & 65 & $11 \%$ \\
5 & Sangat Tidak Setuju & 23 & $4 \%$ \\
\hline
\end{tabular}

Sumber: Diolah penulis (2020)

Melalui penyuguhan data pada tabel 4 dapat diketahui apabila hasil jawaban responden menunjukkan reaksi positif dengan sebanyak 58\% untuk jawaban sangat setuju dan setuju, kemudian dengan $27 \%$ responden memilih menunjukkan sikap tidak pasti atau ragu-ragu untuk pernyataan yang diajukan, sedangkan untuk sisnya sebanyak $11 \%$ dan $4 \%$ menunjukkan sikap negatif atas pernyataan penelitian ini. Sehingga dapat disimpulkan jika Sebagian besar responden pada penelitian ini menunjukkan sikap positif pernyataan yang digunakan, dimana hal tersebut mengidentifikasikan jika responden menunjukkan kesesuaian sikapnya pada indikator penelitian ini saat sedang berminat terhadap suatu produk.

\section{Uji Validitas dan Uji Reliabilitas}

Melalui uji valliditas yang sudah diterapkan terhadap 29 item pernyataan pada penelitian ini, dengan tiap bagian pernyataan untuk variabel X1 (pengetahuan) sejumlah 11 butir kemudian pada bagian religiusitas yang memiliki 12 item pernyataan dan terakhir untuk bagian variabel minat beli terdapat 6 butir pernyataan menunjukkan hasil bahwa keseluruhannya dinyatakan valid. Pernyataan ini diperoleh melalui uji validitas dengan cara membandingkan hasil dari $r_{\text {tabel }}$ dengan $r_{\text {hitung }}$ atau dengan membandingkan hasil nilai signifikansi dengan nilai signifikansi dari probabilitas yang ditentukan. Nilai dari $r_{\text {tabel }}$ sendiri dapat diketahui melalui list dari produk momen, jika nilai dari $\mathrm{r}_{\text {tabel }}>\mathrm{r}_{\text {hitung }}$ maka item pernyataan dinyatakan valid berbanding terbalik jika nilai signifikansi $<$ nilai signifikansi yang ditentukan maka baru akan dikatakan sebagai item pernyataan yang valid. Untuk nilai dari $\mathrm{r}_{\text {tabel }}$ yakni total sampel (n) sejumlah 100 responden juga signifikansi 5\% atau 0,05 yakni sebesar 0,195. Sehingga dapat disimpulkan jika pada penelitian ini setiap item pernyataannya dinyatakan valid dikarenakan telah melebihi nilai dari $\mathrm{r}_{\text {tabel }}$ yang sebesar 0,195 juga nilai signifikansi dari setiap pernyataan yang bernilai 0,00 untuk nilai itu sendiri lebih kecil jika dipadankan dengan nilai signifikansi ketentuan yakni sebanyak 0,05. Maka dari itu untuk uji validitas pada penelitian ini telah dinyatakan lolos untuk dapat digunakan dalam penelitian ini dan dapat melanjutkan pada uji tahap selanjutnya. Setelah dilakukannya uji validitas langkah berikutnya yaitu uji reliabilitas, dimana tahap ini dapat dilakukan secara bersama antara keseluruhan dari item pernyataan. Pada penelitian ini sendiri terdapat total 29 item penyataan sehingga untuk nilai dari cronbach's alpha adalah sebesar 0,888 dimana dengan nilai tersebut item pernyataan pada penelitian ini dapat dikatakan reliabel dikarenakan nilai tersebut telah melebihi dari ketentuan yakni sebesar 0,6. 


\section{Analisis Regresi Linear Berganda}

Uji analisis regresi linear berganda diterapkan dengan tujuan mengkaji pengaruh keterkaitan antara pengetahuan (X1) juga religiusitas (X2) tehadap variabel minat beli (Y), dimana hasil dari uji ini dapat dilihat melalui hasil dari uji $\mathrm{T}$, uji $\mathrm{F}$ dan koefisien determinasi.

\section{a. Uji T}

Hasil dari uji $\mathrm{T}$ ini dapat diperoleh melalui pembandingan antara nilai $\mathrm{t}_{\text {tabel }}$ dengan $t_{\text {hitung }}$ dari setiap variabel $X$. Jika nilai $t_{\text {hitung }}>t_{\text {tabel }}$ atau nilai signifikansinya $<0,05$ maka penelitian ini dinyatakan terdapat hubungan yang signifikan antar variabel independen dan dependennya. Berikut hasilnya:

\section{Tabel 5. Hasil Uji T}

\section{Coefficients $^{\mathrm{a}}$}

\begin{tabular}{llccccc}
\hline \multirow{2}{*}{ Model } & \multicolumn{2}{c}{$\begin{array}{c}\text { Unstandardized } \\
\text { Coefficients }\end{array}$} & $\begin{array}{c}\text { Standardized } \\
\text { Coefficients }\end{array}$ & $\mathrm{t}$ & Sig. \\
\cline { 2 - 5 } & & $\mathrm{B}$ & Std. Error & Beta & & \\
\hline 1 & (Constant) & 3,464 & 2,106 & & 1,645 & 0,103 \\
& Pengetahuan (X1) & 0,217 & 0,066 & 0,322 & 3,302 & 0,001 \\
& Religiusitas (X2) & 0,355 & 0,136 & 0,255 & 2,607 & 0,011 \\
\hline
\end{tabular}

Sumber: Diolah penulis (2020)

Berdasarkan tabel 5 hasil pengolahan uji t memperlihatkan jika hasil thitung juga hasil signifikansi dari kedua variabel independen pada penelitian ini menunjukkan pengaruhnya pada variabel dependen. Pada bagian variabel pengetahuan sendiri nilai signifikansinya adalah sebanyak 0,001 , hal itu lebih kecil dari 0,05. Kemudian untuk hasil thitung pun lebih besar dari hasil tabel yakni $3,322>1,9847$. Untuk hasil pada bagian variabel religiusitas nilai signifikansinya adalah sebesar 0,011 dimana nilai tersebut juga lebih kecil dibandingkan 0,05 serta hasil thitung sebesar 2,607 juga lebih besar dari tabel yang hanya sebesar 1,9847. Sesuai dengan hasilnya bisa dikatakan jika memang kedua variabel X penelitian ini (knowledge dan religiosity) yang masing-masing (parsial) berpengaruh dengan positif juga signifikan pada variabel $\mathrm{Y}$ (minat beli) atau lebih tepatnya hipotesis satu $\left(\mathrm{H}_{1}\right)$ dan hipotesis kedua $\left(\mathrm{H}_{2}\right)$ penelitian ini diterima.

\section{b. Uji F}

Jika uji t diterapkan dengan tujuan guna mencari tahu hubungan secara parsial antar variabel maka uji $\mathrm{f}$ diterapkan guna mencari tahu keterkaitan dengan cara bersama sama (simultan) antara 2 variabel $\mathrm{X}$ atau lebih terhadap variabel $\mathrm{Y}$. Untuk mendapatkan hasil dari uji $\mathrm{f}$ yang signifikan diperlukan beberapa syarat yakni apabila nilai $\mathrm{f}_{\text {hitung }}>\mathrm{f}_{\text {tabel }}$ atau nilai signifikasinya $<0,05$. Adapun hasilnya: 
Tabel 6. Hasil Uji F

ANOVA $^{\mathrm{a}}$

\begin{tabular}{clccccc}
\hline & Model & Sum of Squares & Df & Mean Square & F & Sig. \\
\hline 1 & Regression & 524,643 & 2 & 262,322 & 15,116 & $\mathrm{O}_{0}, 000^{\mathrm{b}}$ \\
& Residual & 1683,357 & 97 & 17,354 & & \\
& Total & 2208,000 & 99 & & & \\
\hline
\end{tabular}

Sumber: Diolah penulis (2020)

Melalui pemaparan hasil uji $\mathrm{f}$ pada tabel 6 memperlihatkan jika hasil signifikansi yang dihasilkan sebanyak 0,000 hasil itu lebih kecil dibandingkan pada nilai signifikansi 0,05 , selain itu untuk nilai $f_{\text {hitung }}$ juga menunjukkan bahwa nilainya lebih besar dibandingkan $\mathrm{f}_{\text {tabel }}$ yakni sebesar 15,116 > 3,089. Hal ini menunjukkan jika 2 variabel $X$ penelitian ini, variabel pengetahuan dan religiusitas secara bersama-sama (simultan) berpengaruh secara positif juga signifikan pada variabel dependen yakni minat beli atau dapat dikatakan jika hipotesis ketiga $\left(\mathrm{H}_{3}\right)$ diterima.

\section{c. Uji Koefisien Determinasi}

Pada penelitian ini penggunaan uji koefisien determinasi ditujukan guna mencari tahu persentase pengaruh dari variabel $\mathrm{X}$ penelitian ini pada variabel $\mathrm{Y}$, dimana hal itu diketahui melalui hasil tabel $\mathrm{R}^{2}$ ini:

Tabel 7. Hasil Uji Koefisien Determinasi $\left(\mathbf{R}^{2}\right)$

Model Summary

\begin{tabular}{|c|c|c|c|c|}
\hline Model & $\mathrm{R}$ & R Square & $\begin{array}{c}\text { Adjusted R } \\
\text { Square }\end{array}$ & $\begin{array}{c}\text { Std. Error of the } \\
\text { Estimate }\end{array}$ \\
\hline 1 & $0,487^{\mathrm{a}}$ & 0,238 & 0,222 & 4,166 \\
\hline \multicolumn{5}{|c|}{ Sumber: Diolah penulis (2020) } \\
\hline \multicolumn{5}{|c|}{$\begin{array}{l}\text { Pada tabel } 7 \text { diatas terlihat jika nilai } \mathrm{R} \text { Square didapatkan untuk penelitian ini adalah } \\
\text { sejumlah } 0,238 \text { itu memperlihatkan jika besarnya prosentase pengaruh dari variabel } \\
\text { independen secara simultan yang mempengaruhi variabel dependen adalah sejumlah } \\
23,8 \% \text { selain itu untuk hasil yang tersisa sebanyak } 76,2 \% \text { merupakan pengaruh yang } \\
\text { berasal adari berbagai faktor lainnya. }\end{array}$} \\
\hline
\end{tabular}

7. Hubungan Antar Variabel

a. Pengetahuan Terhadap Minat Beli

Setelah adanya beberapa pemaparan mengenai hasil untuk penelitian ini, sehingga dapat dikatakan jika penelitian ini memberikan hasil, yakni ada pengaruh secara positif juga signifikan untuk variabel pengetahuan dari para mahasiswa muslim yang menempuh pendidikan di wilayah Surabaya terhadap variabel minat beli atas kopi kekinian halal. Ini menunjukkan bahwa ketiga indikator yang berupa tahu, memahami dan aplikasi pada penelitian ini telah sesuai untuk digunakan dalam mengukur bagian pada variabel pengetahuan dari responden penelitian ini. Maka dari itu hal ini membuktikan jika hipotesis 
pertama $\left(\mathrm{H}_{1}\right)$ terbukti dapat diterima dengan artian bahwa adanya pengaruh dari variabel pengetahuan terhadap variabel minat beli.

Berdasarkan hasilnya maka penelitian ini terbukti sejalan dengan penelitian milik Vristiyana, bahwa pengetahuan dari produk halal memberikan pengaruh terhadap minat secara positif dan signifikan, sehingga hal tersebut mengindikasikan jika semakin tinggi tingkatan pengetahuan responden atas produk halal, maka minat beli responden pada produk halal akan semakin meningkat pula. ${ }^{39}$ Begitupun penelitian ini juga sejalan dengan penelitian dari Briliana dan Mursito yang menyebutkan jika pengetahuan adalah salat satu anteseden penting dalam mempengaruhi minat responden terhadap produk halal. ${ }^{40}$

Sedikit banyak hal ini menunjukkan jika pengetahuan memanglah sangat penting untuk dimiliki oleh setiap manusia terutama umat muslim yang haruslah memiliki pengetahuan dasar mengenai produk halal, dikarenakan memang saat ini seringkali dibutuhkan kejelian dan pengetahuan dalam mengidentifikasikan produk yang tergolong halal atau tidak, agar pada saat sedang berminat terhadap sutau produk dan produk yang diminati telah terbeli akan dapat memberikan kepuasan maksimal atas kesesuaian antara ketentuan agama, keinginan dan kebutuhan terhadap produk yang telah terbeli. Hal ini sendiri tentu juga merupakan perintah yang memang harus dijalankan oleh umat muslim dimana semua umat haruslah berpengetahuan, berikut firman Allah dalam QS. Al-Isra' (17): 36 mengenai perintah bagi umat Islam untuk menjadi seseorang yang berpengetahuan:

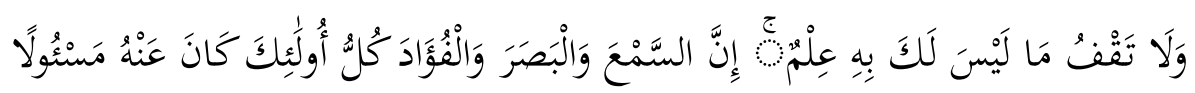

Artinya: "Dan janganlah kamu mengikuti apa yang kamu tidak mempunyai pengetahuan tentangnya. Sesunggubnya pendengaran, pengelibatan dan hati, semuanya itu akan diminta pertanggungjawabanya."

Sesuai dengan QS. Al-Isra' (17): 36 maka umat muslim memang sangat membutuhkan pengetahuan untuk kehidupannya demi dapat mempertanggungjawabkan segala perbuatan dan pilihan hidup yang dijalaninya. Menurut Vristiyana pengetahuan sendiri dapat dikatakan sebagai informasi yang tersimpan pada ingatan, dimana hal tersebut cenderung mengacu terhadap fakta, perasaan maupun pengalaman yang diperoleh seseorang maupun kelompok, adapun hal tersebut bisa memperlihatkan bentuk dari kesadaran maupun kedekatan yang didapatkan dari pengalaman yang pernah dialami ataupun pembelajaran. $^{41} \quad$ Sehingga pengetahuan akan semakin menunjukkan peningkatannya jika terdapat pengalaman baru maupun pembelajaran baru yang diperoleh. Pada segi sudut pandang produk halal pun pengetahuan sangat

\footnotetext{
${ }^{39}$ Vristiyana, "Pengaruh Religiusitas Dan Pengetahuan Produk Halal Terhadap Penilaian Produk Halal Dan Minat Pembelian Produk Halal."

40 Briliana and Mursito, "Exploring Antecedents and Consequences of Indonesian Muslim Youths' Attitude towards Halal Cosmetic Products: A Case Study in Jakarta."

${ }^{41}$ Vristiyana, "Pengaruh Religiusitas Dan Pengetahuan Produk Halal Terhadap Penilaian Produk Halal Dan Minat Pembelian Produk Halal."
} 
berarti untuk digunakan terutama pada saat baru memulai untuk mengenal produk halal, dimana nantinya kesadaran akan pentingnya mengkonsumsi produk halal akan semakin meningkat. Cara yang bisa dilakukan guna menjadikan seseorang sadar mengenai konteks produk halal terutama persoalan higienitas juga keselamatan yang menjadi maksud atas halal yakni dengan memberikan sebuah pendidikan yang dapat menjadikan orang tersebut mengerti tentang betapa pentingnya dalam menentukan pilihan yang tepat untuk dirinya konsumsi dalam kehidupan seharai-hari. ${ }^{42}$

Maka dari itu mahasiswa dipilih sebagai sampel dalam penelitian ini dikarenakan pendidikan yang memang dapat menjadi salah satu pengembang dalam menentukan tingkat pengetahuan seseorang, dimana hal tersebut diharapkan jika pengetahuan dari responden tinggi maka dapat meningkatkan minat beli terhadap kopi kekinian halal. Setelah pendidikan terdapat asal perguruan tinggi sebagai salah satu faktor yang diindikasikan berepengauh pada karakteristik responden, karena seringnya banyak pendapat mengenai kualitas seorang mahasiswa dapat terlihat melalui alamamaternya, namun tentu saja hal tersebut tidaklah benar karena bagaimanapun tetap tergantung dari individu setiap mahasiswa karena bagaimanapun mereka sendiri yang dapat menentukan kualitas diri mereka sendiri terutama jika itu berkaitan dengan pengetahuan. Selain asal perguruan tinggi seringkali banyak pendapat jika usia dapat mepengaruhi tingkatan pengetahuan seseorang, dimana semakin tua seseorang maka semakin tinggi pengetahuan seseorang, akan tetapi berdasarkan tingkatan pengetahuan seseorang menurut pendapat Notoadmodjo mengungkapkan jika pengetahuan seseorang terbagi menjadi tiga tingkatan yakni tahu, memahami dan aplikasi, ${ }^{43}$ sehingga walaupun seseorang telah memiliki usia yang lebih tua belum tentu tingkatan pengetahuannya juga tinggi, karena meskipun mereka lebih berusia yang memang seringkali lebih banyak tahu dan memahami banyak hal karena pengalaman yang dimiliki namun belum tentu mereka telah menerapakan pengetahuan yang mereka tahu dan pahami tersebut dalam kehidupan. Adapun selain tiga hal tersebut seringkali jenis kelamin juga dijadikan sebagai salah satu mengukur pengetahuan seseorang dikarenakan banyak beredar pemahaman bahwa laki-laki seringkali lebih berpengetahuan dibandingkan perempuan dikarenakan laki-laki seringkali berfikir menggunakan logika sedangkan peremmpuan lebih menggunakan hati, namun jelas hal tersebut tidaklah benar karena terbukti banyak perempuan yang berhasil menjadi orang-orang yang berpengaruh di masanya, seperti banyaknya perempuan yang menjadi pemimpin negara, dan lain-lain.

Sehingga dapat disimpulkan jika hipotesis satu diterima dan terdapat pendidikan sebagai salah satu pemicu yang dapat berimbas pada pengetahuan dari responden, dimana jika pendidikan seseorang tinggi, maka seperti halnya seorang mahasiswa maka pengetahuan seseorang cenderung lebih tinggi dibandingkan dengan non mahasiswa seumurannya, sehingga dapat menunjukkan hasil pada minat beli kopi kekinian halal yang lebih tinggi. Berbeda dengan faktor asal perguruan tinggi, usia dan jenis kelamin yang tidak

\footnotetext{
42 Vristiyana.

${ }^{43}$ Notoadmodjo, Metodologi Penelitian Kesehatan, 2007.
} 
dapat menunjukkan pengaruhnya bagi tingkat pengetahuan reponden, hingga dapat mempengaruhi minat beli kopi kekinian halal.

\section{b. Pengaruh Religiusitas Terhadap Minat Beli}

Pada penelitian ini hasil yang dapat dipeoleh dalam pengolahan data mengenai hipotesis kedua $\left(\mathrm{H}_{2}\right)$ adalah jika memang terbukti bahwa variabel religiusitas berpengaruh terhadap variabel minat beli atau dapat dikatakan $\mathrm{H}_{2}$ diterima. Sehingga hal tersebut menunjukkan jika 5 indikator yang dipakai guna mengukur religiusitas pada penelitian ini yakni keyakinan, praktik agama, pengalaman, pengetahuan agama, pengamalan baik dan sesuai dengan penelitian yang dilakukan.

Dengan membuktikan jika hipotesis kedua diterima maka hal ini menunjukkan jika penelitian ini sesuai dengan penelitian yang pernah diteliti oleh, Mutmainah membuktikan jika religiusitas berpengaruh secara positif juga signifikan pada minat beli makanan halal, dimana hal ini menunjukan jika keyakinan yang dianut seseorang dapat menuntun orang tersebut untuk mematuhi aturan agamanya. ${ }^{44}$ Begitupun dengan penelitian dari Hermanto yang juga telah membuktikan jika religiusitas konsumen KFC berpengaruh terhadap minat beli produknya, dimana masih banyak konsumen yang ragu akan status kehalalan produk KFC dikarenakan beragam isu kurang baik mengenai KFC dan KFC yang merupakan brand asal negara Amerika Serikat. Adanya beberapa keraguan dari konsumen menunjukkan jika religiusitas sesorang seringkali tidak hanya bersumber dari individu itu sendiri namun juga berasal dari lingkungan juga baik itu budaya masyarakat maupun ketentuan agama. ${ }^{45}$

Pada dasarnya religiusitas dapat dijadikan umatnya sebagai gaya hidup dalam menjalani segala aspek kehidupan agar dapat terarah sesuai dengan keyakinan dan ketentuan agama yang diyakininya. Agama dan aturannya ada bukan untuk dijadikan pengekang kebebasan namun itu dapat dijadikan sebagai selfcontrol supaya aktivitas yang kita lakukan bisa berlalu dengan baik, benar juga aman. Maka dari itu hendaknya setiap orang mampu untuk menjadikan agamanya sebagai gaya hidup, seperti halnya perintah dari Allah SWT pada umatnya, yakni pada QS. Al-Baqarah (2): 208 berikut:

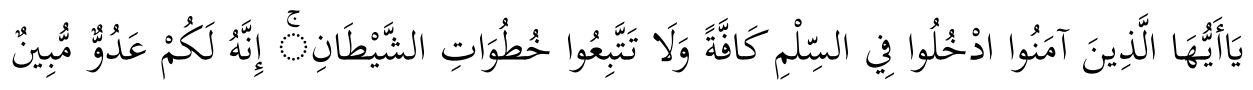

Artinya: "Hai orang-orang yang beriman, masuklah kamu kedalam islam keseluruban, dan janganlah kamu turut langkah- langkah syaitan. Sesunggubnya syaitan itu musub yang nyata bagimu."

Penggalan kalimatnya terdapat kata-kata mengenai "masuk kedalam islam keseluruhan" dimana hal ini sama dengan artinya jika Allah memerintahkan bagi umatnya untuk selalu menerapkan agamnya dalam segala aspek kehidupan,

\footnotetext{
${ }^{44}$ Mutmainah, "Halal Certification, and Food Ingredients on Purchase Intention of Halal Food The Role of Religiosity, Halal Awareness, Halal Certification, and Food Ingredients on The Purchase Role of Religiosity , Awareness , Intention Halal of Halal Food The Role."

${ }^{45}$ Hermanto, "The Analysis of Religiosity and Country of Origin Influence Towards Purchase Intention with Consumer Attitudes as The Intervening Variable in KFC Pandanaran Semarang (Case Study in FE UNISSULA'S Students)."
} 
seperti dalam aspek konsumsi yang memang terdapat perintah untuk hanya mengkonsumsi makanan maupun minuman yang halal.

Pada penelitian ini sendiri dapat dilihat jika sebagian besar pada bagian variabel religiusitas, responden memberikan jawaban sangat setuju dan setuju sebanyak 93\%, hal ini menunjukkan meskipun para responden yang merupakan mahasiswa muslim yang menempuh pendidikan di wilayah Surabaya dan masih berada pada kisaran usia 18-24 tahun mereka telah memiliki religiusitas tinggi meskipun masih pada hal-hal dasar agama, namun mereka tetap mengetahui dan menerapkannya dalam kehidupan sehari-hari. Adapun para responden pada bagian pernyataan mengenai penerapan agama dalam hal selektifitas minuman kopi kekinian hanya terdapat 3 responden yang memberikan jawaban ragu-ragu juga 1 responden memberikan jawaban tidak setuju. Namun pada nyatanya hal tersebut tidak terlalu sejalan dengan hasil jawaban dari peryataan pada bagian variabel minat beli, dimana pada bagian ini respoden hanya memberikan 58\% jawaban sangat setuju dan setuju, dimana sisanya dengan $27 \%$ ragu-ragu dan $15 \%$ adalah jawaban tidak setuju dan sangat tidak setuju. menunjukkan jikalau responden penelitian ini meskipun tingkatan religiusitasnya tinggi untuk bagian penerapan keyakinan, praktik agama, pengalaman, pengetahuan agama dan pengamalan namun masih cukup banyak responden yang tidak benar-benar menerapkan halal lifestyle di kehidupanya sehari -hari terutama saat sedang menikmati kehidupan sosialnya dengan melakukan konsumsi diluar rumah. Sehingga dapat disimpulkan jika repsonden pada penelitian ini memang tingkat religiusitasnya tidak dipengaruhi oleh usia namun meskipun mereka menyatakan jika pilihan konsumsinya dipengaruhi oleh agama, cukup banyak dari mereka yang masih ragu dan tidak setuju atau bahkan sangat tidak setuju dalam menunjukkan minat belinya secara keseluruhan sesuai dengan aturan konsumsi halal dalam islam terutama dalam hal konsumsi kopi kekinian halal.

\section{c. Pengaruh Pengetahuan dan Religiusitas Terhadap Minat Beli}

Melalui hasil dari uji $\mathrm{F}$ dan uji koefisien determinasi yang telah dilakukan penelitina ini, maka dapat dinyatakan jika memang variabel pengetahuan dan religiusitas menunjukkan pengaruhnya secara bersama-sama terhadap variabel minat beli sebanyak 23,8\%. Hal ini dengan tidak lain $\mathrm{H}_{3}$ pada penelitian ini telah diterima.

Hasil penelitian ini menunjukkan kesamaan hasilnya dengan penelitian dari Rohmatun dan Dewi bahwa pengetahuan, religiusitas dan sikap secara simultan berpengaruh signifikan pada niat beli remaja muslim di Indonesia. ${ }^{46}$ Selain itu juga terdapat penelitian dari Vristiyana jika pengetahuan produk halal, religiusitas, dan penilaian produk halal menunjukkan pengaruhnya secara simultan terhadap minat beli mahasiswa muslim pada produk halal khususnya dibidang industri makanan halal di Semarang, penelitian tersebut menunjukkan kesamaan juga pada bagian dimana penggunaan mahasiswa muslim sebagai sampelnya. ${ }^{47}$

\footnotetext{
${ }^{46}$ Rohmatun and Dewi, "Pengaruh Pengetahuan Dan Religiusitas Terhadap Niat Beli Pada Kosmetik Halal Melalui Sikap."

${ }^{47}$ Vristiyana, "Pengaruh Religiusitas Dan Pengetahuan Produk Halal Terhadap Penilaian Produk Halal Dan Minat Pembelian Produk Halal."
} 
Pada penelitian ini penggunaan mahasiswa muslim sebagai sampel itu pun dikarenakan peneliti menganggap secara umum bahwa seharusnya sebagai umat muslim dan seorang mahasiswa hendaknya telah mengetahui dan menerapkan religiusitas dan pengetahuan dasar mengenai produk halal, karena mahasiswa sendiri secara umum dapat dinilai sebagai orang yang memiliki kesadaran lebih akan ilmu pengetahuan dibandingkan dengan non mahasiswa yang seumuran, meskipun memang pengetahuan dan religiusitas setiap mahasiswa memiliki tingkatan yang berbeda-beda. Maka jika tingkatan pengetahuan dan religiusitasnya berada pada tingkatan tinggi, mahasiswa muslim akan menunjukkan minatnya secara lebih terhadap produk-produk halal terutama kopi kekinian halal.

Untuk usia sendiri dalam penelitian ini tidak menunjukkan pengaruhnya pada tingkatan pengetahuan dan religiusitas mahasiswa muslim hingga dapat berpengaruh pada minat belinya. Dapat dilihat jika memang sebagian besar usia responden adalah pada kisaran 18-24 tahun dengan jumlah 95\% dan untuk 5\% ditempati oleh usia kisaran 25-34 tahun, namun tidak sedikit pula hasil yang menunujukkan jika pengetahuan dan religiuistas yang tinggi dari responden dengan kisaran usia 18-24 tahun yang sesuai dengan tingkat minat beli tinggi yang ditunjukkan pada kopi kekinian halal, sebaliknya untuk usia 25-34 tahun tidak semuanya menunjukkan hal yang selaras antara tingkatan pengetahuan dan religiusitas yang tinggi dengan minat belii kopi kekinian halal yang tinggi pula. Sehingga usia pada penelitian ini tidak terlalu mempengaruhi karakterisktik dari responden. Begitupula dengan jenis kelamin dan asal perguruan tinggi tidak menunjukkan pengeruhnya terhadap karakteristik responden karena bagaimanapun baik respondek laki-laki atau perempuan dan berasal dari perguruan tinggi negeri maupun swasta juga tidak menunjukkan pengaruhnya, dikarenakan setiap responden tentunya tetap akan memiliki tingkat religiusitas dan pengetahuan yang berbeda-beda tingkatannya tergantaung dari individu responden itu sendiri saat menunjukkan pengetahuan maupun religiusitasnya dalam mempengaruhi minat belinya pada kopi kekinian halal.

Jika usia tidak memberikan pengaruhnya pada karakteristik responden maka terdapat beberapa hal yang dapat mempengaruhi karakteristik dari responden sehingga berpengaruh pula pada minat beli yang ditunjukkannya pada kopi kekinian halal.

Adapun hal tersebut adalah sumber informasi kehalalan produk kopi kekinian dan pertimbangan yang diambil saat menunjukkan minatnya pada produk kopi kekinian. Kedua hal tersebut dijabarkan dengan lebih spesifik beserta hasil jawaban dari responden yang dapat memberikan jawaban lebih dari satu dari pilihan yang disediakan, dimana pada bagian sumber informasi kehalalan terdapat pembelian produk (37\%), web LPPOM MUI (22\%), iklan(22\%), kemasan produk (61\%), keluarga/ teman/ rekan (37\%), media sosial (56\%) begitupun dengan spesifikasi pada bagian pertimbangan yang diambil responden saat berminat pada produk kopi kekinian yakni sertifikais halal (66\%), kualitas (69\%), harga (69\%), ingrediants (40\%), review produk dari media sosial $(33 \%)$, rekomedasi keluarga/ teman (53\%) dan pembelian produk (37\%). Melalui hasilhasil jawaban responden menunjukkan jika pendapat dari Sciffman dan Kanuk mengenai hal-hal yang dapat menjadi faktor pendorong minat beli seseorang 
adalah teman, pengaruh keluarga, media massa, pemasaran langsung, pengalaman pribadi. ${ }^{48}$ Pada bagian pengalaman pribadi sendiri diwakilkan dengan pilihan pembelian produk pada pilihan dibagian sumber informasi kehalalan produk kopi kekinian dan pada bagian pertimbangan yang diambil saat menunjukkan minat pada produk kopi kekinian, kemudian untuk bagian pengaruh keluarga atau teman diwakilkan dengan keluarga/ teman/ rekan sebagai sumber informasi kehalalan produk kopi kekinian dan rekomendasi dari keluarga/ teman sebagai pertimbangan untuk menunjukkan minatnya pada produk kopi kekinian, selanjutnya di bagian pemasaran langsung diwakilkan oleh kemasan produk untuk sumber informasi kehalalan produk kopi kekinian halal juga sertifikasi halal, kualitas, harga, ingrediants untuk pertimbanngan dalam menunjukkan minat produk kopi kekinian, dan yang terakhir bagian media sosial diwakilkan oleh web LPPOM MUI, iklan, media sosial yang menjadi sumber informasi kehalalan produk kopi kekinian dan untuk review produk dari media sosial sebagai pertimbangan dalam menunjukkan minatnya terhadap produk kopi kekiniaan.

Sehingga bisa dikatakan jika karakter dari responden pada penelitian ini yang merupakan mahasiswa muslim yang menempuh pendidikan di wilayah Surabaya tidak dipengaruhi oleh usia, jenis kelamin, asal perguruan tinggi, dikarenakan hal tersebut tidak serta merta dapat menunjukkan tingkatan pengetahuan dan religiusitas responden yang nantinya akan berpengaruh pada minat beli produk kopi kekinian halal. Selain itu minat beli yang ditunjukkan oleh responden didorong oleh beberapa faktor yaitu teman, pengaruh keluarga media sosial, pemasaran langsung dan pengalaman pribadi.

\section{Kesimpulan}

Melalui data yang telah diperoleh juga sudah diterapkan pengujian, bisa diambil kesimpulan jika pengetahuan yang dimiliki oleh mahasiswa muslim yang menempuh pendidikan di wilayah Surabaya memberikan pengaruhnya terhadap minat beli kopi kekinian halal secara positif dan signifikan dimana hal ini menunjukkan jika perintah dalam QS. Al-Isra' (7): 36 memang haruslah dijalankan guna dapat membantu diri sendiri dalam menyelesaikan masalah kehidupan terutama dalam hal memilih dan memilah makanan dan minumn yang hendak dikonsumsi termasuk kedalam kategori produk halal, serta terdapat pendidikan menjadi salah satu pemicu yang dapat mempengaruhi tingkatan dari pengetahuan responden, dimana jika pendidikan seseorang tinggi maka dapat menunjukkan hasil pada minat beli kopi kekinian halal yang lebih tinggi. Berbeda dengan faktor asal perguruan tinggi, usia dan jenis kelamin yang tidak dapat menunjukkan pengaruhnya bagi tingkat pengetahuan reponden, hingga dapat mempengaruhi minat beli kopi kekinian halal.

Untuk religiusiatas yang mereka miliki juga memberikan dampak yang sama yakni berpengaruh secara positif juga signifikan pada minat beli kopi kekinian halal. Repsonden pada penelitian ini memang tingkat religiusitasnya tidak dipengaruhi oleh usia namun mereka menyatakan jika pilihan konsumsinya dipengaruhi oleh agama, cukup banyak dari mereka yang masih ragu dan tidak setuju atau bahkan sangat tidak setuju dalam

\footnotetext{
${ }^{48}$ Schiffman, Leon G dan Kanuk, Perilaku Konsumen.
} 
menunjukkan minat belinya secara keseluruhan sesuai dengan aturan konsumsi halal dalam islam terutama dalam hal konsumsi kopi kekinian halal. Sedangkan dalam pengujian secara simultan antara pengetahuan dan religiusitas terhadap minat beli kopi kekinia halal menunjukkan hasil yang positif dan signifikan pula. Hal ini mmebuktika jika memang seluruh hipotesis dalam penelitian ini diterima.

Adapun saran untuk penelitian selanjutnya adalah agar bisa menambahkan variabel independen lain yang dapat berpengaruh terhadap minat beli maupun menambahkan variabel intervening yang mendukung, selain itu dapat pula penelitian selanjutnya menggunakan objek penelitian lain selain kopi kekinian halal, dikarenakan pembahasan mengenai produk halal masih begitu banyak dan luas jangkauannya. Begipula untuk sampel dapat pula menggunakan yang sampel yang lebih spesifik guna mendukung objek yang diteliti seperti penggunaan sampel mahasiswa yang menempuh pendidikan di perguruan tinggi islam ataupun mahasiswa yang menempuh program studi yang menggunakan Islamic basic sebagai matakuliah yang diajarkan.

\section{Daftar Pustaka}

(Ibnu Majah), Abdullah Muhammad bin Yazid bin Majah ar-Rabi'i Al-Qazwini. Sunan Ibnu Majah, Pub. L. No. 3383 (n.d.).

Al-Maragi, Ahmad Mustafa. Tafsir Al-Maragi. Juz 2. Semarang: PT. Karya Toha Putra, 1993.

Ancok, D dan Suroso, F. N. Psikologi Islami: Solusi Islam Atas Problem-Problem Psikologi. Yogyakarta: Pustaka Pelajar, 1994.

Briliana, Vita, and Nurwanti Mursito. "Exploring Antecedents and Consequences of Indonesian Muslim Youths' Attitude towards Halal Cosmetic Products: A Case Study in Jakarta." Asia Pacific Management Review 22, no. 4 (2017): 176-84. https://doi.org/10.1016/j.apmrv.2017.07.012.

Cahya, Putriana. “Tren Kopi Susu Kekinian, Akankah Segera Berlalu?” IDN.Times, 2019. https://jabar.idntimes.com/news/indonesia/putriana-cahya/tren-kopisusu-kekinian-regional-jabar/full.

Hermanto, Edwin. "The Analysis of Religiosity and Country of Origin Influence Towards Purchase Intention with Consumer Attitudes as The Intervening Variable in KFC Pandanaran Semarang (Case Study in FE UNISSULA'S Students)." International Jurnal of Islamic Business Ethics (IJIBE) 3, no. 2 (2018): 47382.

Hidayati, Tri Asih, Suharyono, and Dahlan Fanani. "Pengaruh Citra Merek Terhadap Minat Beli Dan Keputusan Pembelian Konsumen." Administrasi Bisnis (JAB) 2 No. 1 (2013).

Jalaluddin. Psikologi Agama. Jakarta: Raja Grafindo Persada, 2009.

Jawa Timur, BPS. "Jumlah Perguruan Tinggi, Mahasiswa Dan Tenaga Edukatif (Negeri Dan Swasta Di Bawah Kemetrian Riset, Teknologi Dan Pendidikan Menurut Kabupaten/ Kota Di Jawa Timur Tahun 2018/ 2019," 2019. https://jatim.bps.go.id/statictable/2019/10/09/1658/jumlah-perguruan-tinggimahasiswa-dan-tenaga-edukatif-negeri-dan-swasta-di-bawah-kementrian-riset- 
teknologi-dan-pendidikan-menurut-kabupaten-kota-di-jawa-timur-2018-2019.html.

KBBI. "Kamus Besar Bahasa Indonesia (Online)," 2020. https://kbbi.web.id/kini. "Kamus Besar Bahasa Indonesia (Online)," 2020. https://kbbi.web.id/minat.

- "Kamus Besar Bahasa Indonesia (Online)," 2020. https://kbbi.web.id/pengetahuan.

. "Kamus Besar Bahasa Indonesia (Online)," 2020. https://kbbi.web.id/religius.

LPPOM MUI (Lembaga Pengkajian Pangan, Obat-obatan, dan Kosmetika Majelis Ulama Indonesia). "Kopi? Sudah Pasti Halalkah? Pelajari Titik Kritis Kehalalan Kopi." LPPOM MUI, 2019. https://www.halalmui.org/mui14/main/detail/kopi-sudahpasti-halalkah-pelajari-titik-kritis-kehalalan-kopi\#.

Lucas, D. B dan Britt, S. H. Advertising Psychology and Research. New York: Mc Graw- Hill, 1950.

Maghfiroh As'alul, Zainul Arifin, Sunarti. "Pengaruh Citra Merek Terhadap Minat Beli Dan Keputusan Pembelian.” Jurnal Administrasi Bisnis (JAB) 40, no. 1 (2016): 132 40.

Menteri Agama Republik Indonesia. Tentang Penyelenggaraan Jaminan Produk Halal (2019).

MUI (Majelis Ulama Indonesia). Tentang Hukum Alkohol (2009).

Mutmainah, Lu. "Halal Certification, and Food Ingredients on Purchase Intention of Halal Food The Role of Religiosity , Halal Awareness, Halal Certification, and Food Ingredients on The Purchase Role of Religiosity , Awareness , Intention Halal of Halal Food The Role." (HTIF AZ) Journal of Islamic Economics, Finance and Banking 1, no. 1 dan 2 (2018).

Notoadmodjo, Soekidjo. Metodologi Penelitian Kesehatan. Jakarta: Rineka Cipta, 2007. . Metodologi Penelitian Kesehatan. Jakarta: Rineka Cipta, 2012.

Rohmatun, Karina Indah, and Citra Kusuma Dewi. "Pengaruh Pengetahuan Dan Religiusitas Terhadap Niat Beli Pada Kosmetik Halal Melalui Sikap." Jurnal Ecodemica 1, no. 1 (2017): 27-35.

Schiffman, Leon G dan Kanuk, Beslie Bazar. Perilaku Konsumen. Ketujuh. PT. Indes, 2008.

Septyaningsih, Lit. Dan Nora Azizah. "Bisnis Ready to Drink Coffee Terus Meningkat." Republika.co.id, 2019. https://gayahidup.republika.co.id/berita/q2ngyv463/bisnis-emready-to-drinkcoffeeem-terus-meningkat.

Sjamsuri. Pengantar Teori Pengetahuan. Jakarta: Departemen Pendidikan dan Kebudayaan Direktorat Jendral Pendidikan Tinggi, 1989.

Sugianto, Danang. "Hasil Riset: Kedai Kopi Di RI Bertambah 2.000 Dalam 3 Tahun." Detik Finance.com, 2019. https://finance.detik.com/berita-ekonomi-bisnis/d4826275/hasil-riset-kedai-kopi-di-ri-bertambah-2000-dalam-3-tahun.

Utami, Ruri Putri, and Hendra Saputra. "Pengaruh Harga Dan Kualitas Produk Terhadap 
Minat Beli Sayuran Organik Di Pasar Utami, Ruri Putri Saputra, Hendrasambas Medan 1)." Jurnal NIAGAW AN 6, no. 2 (2017): 44-53.

Vristiyana, Visca Mirza. "Pengaruh Religiusitas Dan Pengetahuan Produk Halal Terhadap Penilaian Produk Halal Dan Minat Pembelian Produk Halal." EKOBIS 20, no. 1 (2019): 85-100. 